Rapp. Grønlands geol. Unders. 58, 33-35 (1973)

\title{
HEAVY METAL CONTENT OF THE POSIDONIA SHALES ON WEGENER HALV $\varnothing$
}

\author{
Bjørn Thomassen
}

\section{Introduction}

In the summer of 1968 two prospectors from Nordisk Mineselskab A/S examined a number of mineral indications on Wegener Halv $\varnothing$, which had been described by Eklund (1944). During the work they discovered that the bituminous Permian shales, the Posidonia shales, first found at this locality by Noe-Nygaard (1934), showed rather high contents of copper and lead minerals. At ten localities examined nine showed signs of mineralization (Lehnert-Thiel, personal communication, 1968) and it was therefore decided to make a detailed sampling profile the following year.

In 1969 four men, including the writer dug a $20 \mathrm{~m}$ long trench up to $1.6 \mathrm{~m}$ deep through the Posidonia shales in order to obtain fresh samples. The trench was situated about $550 \mathrm{~m}$ a. s. 1. in the south-west part of the valley of Vimmelskaftet on Wegener Halv $\varnothing$ (fig. 1). Under the Posidonia shales a stratum of reefy limestone forms a vertical wall $50-100 \mathrm{~m}$ high, and the shales themselves are covered by steep slopes of scree. In the trench, which ran from the reef upwards through the lowermost $16 \mathrm{~m}$ of the shales, a continuous 5 by $5 \mathrm{~cm}$ channel sample was excavated and divided in 39 parts corresponding to lithological units.

\section{Type of mineralization}

The Posidonia shales on Wegener Halvø cover an area of about $100 \mathrm{~km}^{2}$. Furthermore they are found in a zone extending northwards to Clavering $\emptyset\left(74^{\circ}\right.$ $15^{\prime}$ ) and are supposed to underlie the Mesozoic sediments of Jemason Land to the south (Maync, 1942). They are dark grey to black, bituminous, marly shales interbedded with grey, bituminous limestone. Resting conformably on a light grey, reefy, dolomitic limestone, they grade upwards into dark limestones and arenaceous sediments. The shales of the trench locality dip $22^{\circ}$ to the west.

Macroscopically the sulphides are only recognized as scattered grains of pyrite, chalcopyrite and galena of millimetre size in the limestone beds, as well as in a few millimetres thick secondary calcite veins. Microscopically Lehnert-Thiel de- 


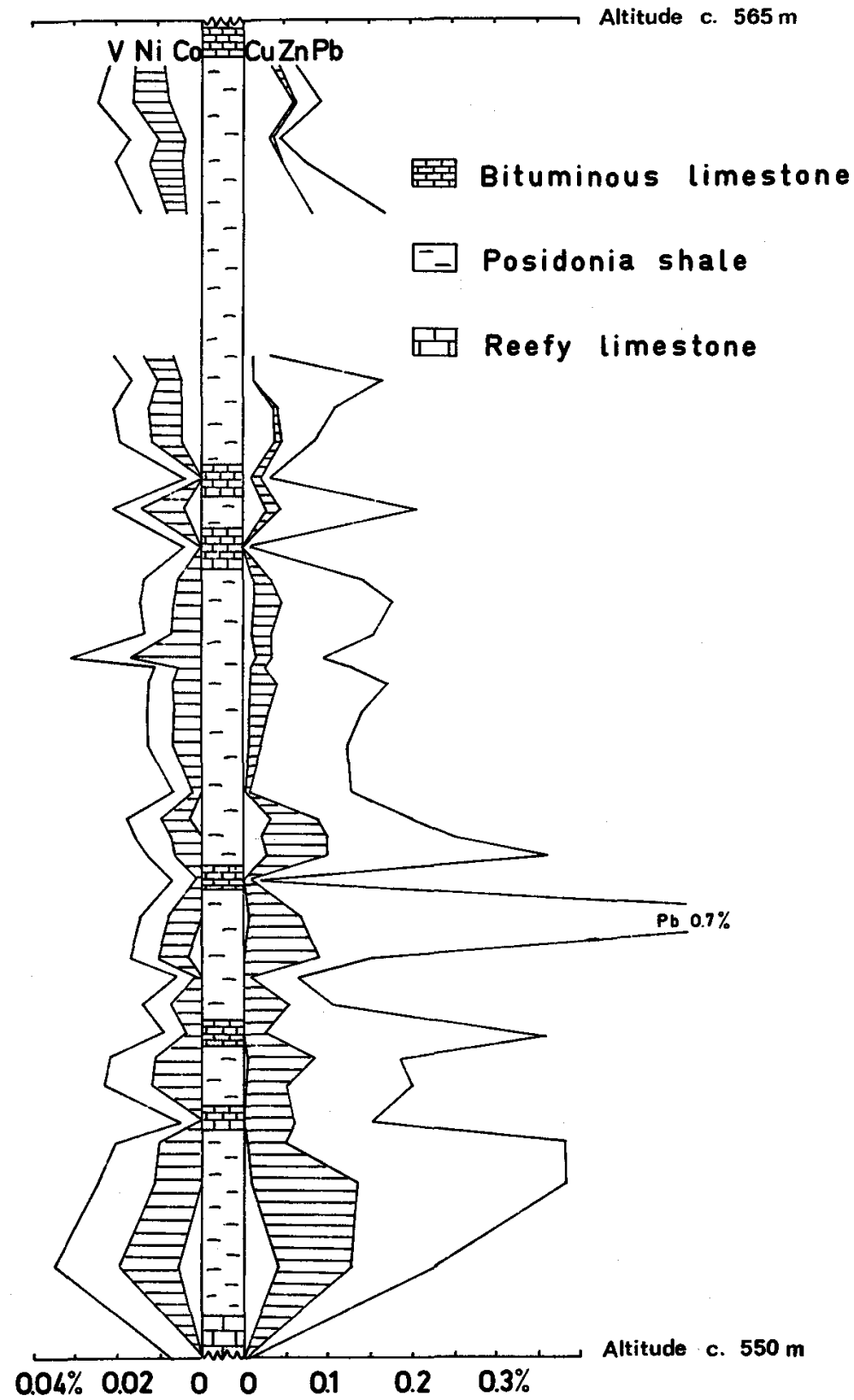

Fig. 3. Diagram of analysis along a profile trench through the Posidonia shales at Vimmelskaftet, Wegener Halvø. 
tected the following sulphides: galena, sphalerite, chalcopyrite and minor arsenopyrite and fahlerz in ore mineral concentrations. He characterizes the mineralization as of typical syngenetic sedimentary nature and compares it with the contemporaneous Zechstein Kupferschiefer in Europe.

\section{Results of analyses}

The samples were analysed at the Institut for Petrologi, Copenhagen University. $\mathrm{Pb}, \mathrm{Cu}, \mathrm{Mo}, \mathrm{Ag}, \mathrm{Co}, \mathrm{Ni}$ and $\mathrm{V}$ were determined spectrographically by $\mathrm{H}$. Bollingberg and Zn by means of XRF by J. C. Bailey and the writer. The results are shown diagramatically on fig. 3. Mo only exceeds the detection limit $0.003 \%$ in four samples from the bottom of the section with maximum contents of $0.008 \%$ and is therefore excluded. Ag which exceeds the detection limit $0.001 \%$ in only three samples from the top of the section, with a maximum of $0.003 \%$ is also excluded. The maximum $\mathrm{Pb}$ contents of $0.7 \%$ were checked by XRF.

From the diagram (fig. 3 ) it appears firstly that the metal concentrations are less in the limestone beds than in the surrounding shales. Secondly that the concentrations of $\mathrm{Pb}, \mathrm{Zn}, \mathrm{Ni}$ and $\mathrm{V}$ decrease upwards in the strata, while the concentrations of $\mathrm{Cu}$ and $\mathrm{Co}$ seem to increase upwards. This is the reverse of the European Kupferschiefer where the $\mathrm{Cu} / \mathrm{Zn}$ ratio decreases upwards.

\section{Final remarks}

The Posidonia shales are considered to have been deposited in the stagnant water of more or less closed sea basins. This means that both lateral and vertical variations in the metal concentrations can be expected in the separate basins, as well as in different concentrations in different basins. Even if the examined section does not show a deposit of economic value, it indicates a type of mineral deposit which has been of great importance in Europe, and it would therefore be of interest to continue the investigations of the Posidonia shales at other localities on Wegener Halvø and elsewhere in East Greenland.

\section{References}

Eklund, O. 1944: Malmgeologisk forskning på Nordostgrønland. Teknisk Tidskr. 74, 393-401. Maync, W. 1942: Stratigraphie und Faziesverhältnisse der oberpermischen Ablagerungen Ostgrönlands. Meddr Grønland 115(2), 128 pp.

Noe-Nygaard, A. 1934: Stratigraphical outlines of the area round Fleming Inlet (East Greenland). Meddr Grønland 103(1), 88 pp. 